\title{
Embedding Critique in the University: A New Role for Critical Marketing Education?
}

\author{
Dr. Ming Lim* \\ University of Leicester \\ School of Management \\ Ken Edwards Building \\ Leicester LE1 7RH \\ $\mathrm{Ph}:+44(0) 116-252-3999$ \\ Fax: $+44(0) 116-252-5515$ \\ Email: $\underline{\text { m1170@leicester.ac.uk }}$
}

\author{
Dr. Peter Svensson \\ Department of Business Administration \\ Lund University \\ PO-Box 7080, SE- 22007 \\ Lund, Sweden \\ $\mathrm{Ph}:+46-46-2220186$ \\ Fax: +46-46-222 4437 \\ Email: Peter.Svensson@fek.lu.se
}

*Please address all correspondence to this author. 


\title{
Embedding Critique in the University: A New Role for Critical Marketing Education?
}

\begin{abstract}
This paper critically re-examines the role of the university as a site of (declining) social, cultural and political power and influence in the aftermath of the development of the 'entrepreneurial university'. Although scholars have identified the dangers of such a scenario, few attempts have been made to offer a pragmatic solution to preserve, or even rejuvenate, the university as an agent of critique. This paper proposes a novel answer by arguing that a critical marketing education can take over this role in the academy where traditional critical agents like the arts and humanities are widely acknowledged to have failed. Using a historical-critical approach, and by conceiving of 'critique' as a heterogeneous, multidimensional amalgam of both business and the humanities, the paper shows how a critical marketing education offers a pragmatic means of preparing university students to become active and critical voices of society.
\end{abstract}

Keywords: Critique, Higher Education, Critical Marketing, Marketing Education, University 


\section{Introduction}

Over the last three decades, the university has emerged as a site of knowledge production and, as such, a net contributor to economic development and technological transformation on a global scale (see Perry, 2006; Urry, 2002; Delanty, 2001). In the U.K. and the U.S., academics have witnessed, and also participated in, the commodification of the results of such production. Although a number of critical voices have been raised from within the management academy (e.g. Ford, Harding and Learmonth, 2010), the problem has been identified across the disciplinary spectrum as a kind of contagion which has spread across global academic markets (Slaughter and Leslie, 1997; Ehrenberg, 1997; Kennedy, 1997; Tierney, 1997; Noll, 1998). The instrumentalist discourse is now unquestioningly accepted, sold and bought by university administrators and leaders throughout the U.K., Europe and the United States: "it is not enough for universities simply to produce knowledge; they must actively transfer that knowledge to industry, user and community groups" (May and Perry, 2006: 263).

In a similar vein, Czarniawska and Genell (2002) argue that universities' identities are now shaped by market forces rather than traditional conceptions of knowledge production. O'Neill and Solomon (1996) refer to this tendency as the 'incursion by the markets' into higher education (cited in Mautner, 2005: 98). When the educational system undergoes such marketization, "institutions of higher education come increasingly to operate (under government pressure) as if they were ordinary businesses competing to sell their products to consumers" (Fairclough, 1995: 141). The pedagogical implications are stark. Students are conceived of as 'customers,' or, more bafflingly, as 'guests,' as 
though universities were hotels or spas. They are theorized as consumers or co-producers of experiences which should be made as engaging as possible in order to promote loyalty and favourable word-of-mouth. Nowadays, the university is even regarded as some kind of business person or enterprise. Thus, increasingly we hear talk of the "entrepreneurial university," the "university-industry partnership" and so on, all pointing to the university as a site of commodification and marketization (Helmsley-Brown, 2011). This is a development with many consequences. One such consequence is that universities are, to a great extent, now supposed to engage in competitive branding and positioning on a market of education. Knowledge is thereby treated and managed as one of the commodities offered by the industry of higher education which has altered professional roles as well as relations between students (customers) and teachers (service providers).

Another consequence of the entrepreneurialism embarked upon by universities in recent decades is a marked change in how universities appear to want to perceive themselves, and be perceived, by students, parents, the public, policymakers and other audiences. Universities rarely, if ever, now consider themselves as arbiters of 'truth' and 'critical inquiry'; instead, they are businesses focused on league table rankings, income generation, internationalization, marketization and so on (Lowrie and Willmott, 2006; Readings, 1996; Molesworth, Scullion and Nixon, 2011). However, finding tangible solutions is more difficult than acknowledging the problem. While the arts and humanities show potential for tackling some of the world's most intractable problems in a creative way (Griffin, 2006) and appear, at least to some, to provide alternative visions to totalizing paradigms of thought, there is no doubt that their status within the academy is more precarious than ever, due to funding constraints and a culture which valorizes the 
power of science and technology. Where 'science' has dominated funding parameters and headlines, the arts and humanities have become invisible, seemingly mired in the rhetoric of despair (Mautner, 2005; Webster, 2003).

Given these dangers, the question is: "what can academics do to push back harder against the forces of commercialization", to "counter and reverse the worldwide tendency to accelerate and expand the commodification of higher education in the twenty-first century”? (Benson and Harkavy, 2002: 173).

This paper, therefore, revisits the question of the University as a "site of critique" (Readings, 1996: 6) in order to propose what we believe is a pragmatic contribution to the discussion. Any viable approach to this important issue, we believe, should not attempt to ignore or simply decry the current "instrumentalization of the university as it embraces market values and information technology" (Delanty, 2001: 150) and the transformation of the scope of academic freedom to the funding powers of the State, from which, as Conrad Russell (1993) soberly notes, "there is no safe escape" (p. 48). Rather, a consideration of the historical antecedents of the impact of entrepreneurialism upon the university may well throw up new possibilities for action in the academy that have a real impact upon the wider world and marketplace which our students enter upon graduation.

Bearing in mind the decline of the role of the Humanities (and especially philosophy) as the foundational discipline of critique, this paper asks, therefore: how can universities preserve their critical function in the knowledge economy? Which discipline or subdiscipline should now perform the critical function within the University in the 
knowledge economy? Finally, how would such a disciplinary alternative work in practice?

Some valuable attempts have been made to address questions of this nature. Catterall, MacClaran and Stevens (2002) and Tadajewski and Brownlie (2008), for instance, argue convincingly for critically reflective theory and practice to penetrate marketing education in the classroom. Others have called for critical marketing education and its prerequisites to be an essential part of the curriculum for all university students because of its relevance for humanistic inquiry (Petkus 2007; Hill and McGinnis 2007). A key assumption of these arguments is that marketing must somehow empower students to look in two directions at once: within organizations and without, to the world beyond the classroom. Therefore, critical marketing education needs to redress a narrow focus on intra-organizational competencies which neglect the challenges and opportunities of "managing within wider moral, political, and societal contexts" (Catterall, MacClaran and Stevens, 2002: 185; see also Ellis, Fitchett, Higgins, Jack, Lim, Saren and Tadajewski, 2010).

Few arguments along these lines, however, map critical marketing education in terms of the function of academic critique that has impacts far beyond the walls of academia. No known research to date has embraced the radical notion that critical marketing education can be a potent carrier of, and agent for, the traditional function of critique in the University. This paper proposes that marketing education, for reasons we describe in the rest of this paper, can be crafted and developed to take over the some of the critical function in universities. Marketing education has the potential to equip students for their 
future professional lives in business as critics - or philosophers - of society. Critical marketing education today offers a way to equip its graduates with critical thinking, reasoning and moral skills - all the skills of philosophy, in other words - while simultaneously preparing them to enter the business world (if they choose to do so).

This strategy we call "embedding the critic" in the university as well as in society. Instead of going round in circles arguing for or against the autonomization or deautonomization of universities (depending on which side of the moral debate one is on), we propose that universities actively seek to embed critics in society. Instead of only reacting to industry needs, the university needs to remember philosophy's activist origins and plant qualified critics into industry - in the midst of the market. Furthermore, it is argued that marketing education provides the tools and industry knowledge to allow students to exercise critique not only within, but also beyond, the academy. The critical study of marketing equips students not only with a knowledge of the paradigms, tools and dogmas of conventional marketing methods but also of the failures and dangers of the market itself and how it operates economically, socially and ideologically. Given the marketization of vast sectors of the economy and society today, marketing education offers its students a unique perspective on how to criticize society from within, as well as from without. This feature of critical marketing, we argue, makes it quite different from other mainstream management disciplines such as HRM, Operations Management, Finance, Accounting or Organizational Behaviour or their 'critical' variants, now wellestablished within the Academy of Marketing as 'Critical Management Studies' (CMS). Even the adherents of CMS acknowledge the difficulties involved in getting its activist and humane agendas noticed in public discourse, let alone influence societal practices to 
any significant degree (Bridgman, 2008; Böhm and Spoelstra, 2004). Can a solution be found to the frustrating lack of progress in this area without resorting to the power of individual morality and conscience - always a hard road to take! - or by looking outside the academy for inspiration (Bridgman and Stephens, 2008)?

We contend that critical marketing education may well be a particularly apposite candidate at business schools for such a change to take place so that the role of critique can, once again, flourish within universities. We suggest that the first step could well be to accept, not just bemoan or despair of, the ubiquity and unquestioned power of the market. Today, the notion of 'the market' has spread to a vast variety of institutions and practices in society, e.g. education, healthcare and politics (Mautner, 2010). Thus, activities such as branding, positioning, selling and advertising are no longer only a matter for corporate marketing departments but have become crucial for universities and hospitals in their attempts to compete on markets of education and healthcare. There are therefore, we argue, reasons to regard marketers (and, by inference, students of marketing) as, potentially, one of the most influential groups of social architects of contemporary market and consumer society. If we can accept marketization as friend even provisionally -- rather than arch-enemy, could students of marketing not be enrolled into new spheres of influence and power within society?

To provide greater clarity to our argument, it was decided to present two examples, or sites, where both the problem and the solution may be said to co-exist: the U.K. and Sweden. Both systems of education share important differences, but also face similar challenges. Both systems were founded on the philosophy of intellectual freedom and 
cultural autonomy (the conditions for 'critique' to flourish) but were always already, at the same time, also subject to political pressures from the State, and increasingly, the 'market'.

\section{Method}

For the purposes of our paper, it was felt that a historically situated literature review would be most appropriate (cf. Fullerton, 1987, 1988; Nevett, 1991); by this we mean that we focus on how marketing education can be illuminated by a historical appreciation of the roots of 'critique' within the academy and its wider institutional setting. Our approach takes inspiration from recent scholarship which calls for historical approaches to marketing and for an understanding of how marketing ideas are perpetuated and entrenched (e.g. Tadajewski, 2010a; 2010b; Tadajewski and Hewer, 2011) although it differs from them in focusing on the evolution of critique rather than on the marketing discipline itself. Although historical approaches in the field of marketing are still evolving and raise issues of reflexivity and relevance for marketing academics, the use of historical analysis in marketing is gaining currency for its ability to highlight patterns of change and identify effects and implications; marketing scholars contend that this method "suggests that historical phenomena can be rich and complex and that they can best be understood by investigating the time(s), place(s), and context(s) in which they arise and develop" (Low and Fullerton, 1994: 173). Such an investigation emphasizes "critical evaluation - exacting and probing analysis to detect hidden agendas, self-serving arguments, inaccuracies, and the influences of now-extinct ideas, current when the data were created" (Low and Fullerton, 1994: 174). Moreover, a historical approach can provide explanations for likely developments in the future, although it cannot predict 
these with any accuracy (Nevett, 1991). We thus "read" primary and secondary sources in the light of our overall thesis and use multiple data sources wherever possible to support out argument. Data sources include White Papers, archival material, government and press reports as well as other secondary data from British and Swedish universities and other public institutions. These two sites - British and Swedish universities - were chosen for two reasons. First, the U.K. has, over the last two decades, embarked upon a marketized model of education (Foskett, 2011; Hemsley-Brown, 2011; Gibbs, 2001) more rapidly than in almost any other developed economy and with far-reaching consequences. Since the global financial crisis of 2008, the withdrawal of state funding for universities has only accelerated, resulting in greatly increased tuition fees for undergraduates and a plethora of funding cuts for programmes, research and investments in infrastructure and staff recruitment. As a site of contrast, Swedish universities present a useful example of a transitional market system. Although still largely state-funded, many of its universities are also advocating managerialist structures found in corporations, such as a focus on PR and branding activities, establishing links with industry, competing for students and money from non-traditional sources (Hedmo and Wedlin, 2008; Gornitzka, Maassen, Olsen and Stensaker, 2007; Czarniawska and Genell, 2002). Second, both authors work in these two sites and have spent periods of leave and research at institutions in both the U.K. and Sweden. To this extent, the choice of these two sites made convenience sampling a logical methodological choice.

\section{Review of 'Critique' in the Academy}

The notion of 'critique' itself has a long history. Derived from the Greek kritike (art of criticism), it has been used, since the 18th century, to refer to the review or interrogation 
of ideas or concepts. Unlike the verb most closely associated with it - 'criticize' - it denotes the disinterested review, judgement and organized dissemination of silenced or minoritarian voices and agendas without prejudice or bias.

Scholars have defended the special role of the humanities as a kind of vanguard of "intellectual and political resistance" against the capitulation to academic capitalism (Miyoshi, 2002) but it is important to ask why critique is important to preserve for its own sake. The scrutiny of this state of affairs only occurred in the early $19^{\text {th }}$ century. Consequently, "critique" was added, as it were, to the agenda of universities. The faculty of critique is profoundly related to the practice of philosophy and draws its impetus from the German Idealists. Their theses on the institution known as the university are particularly provocative in this regard. As Fichte (1807) put it, the university exists not to pass on information but to inculcate critical judgement. In The Conflict of the Faculties, Kant (1979) lays out the enviable topography of philosophy as the "lower" faculty which escapes the censorship of the State as long as it confines itself to the exercise of truth within the university. Philosophy thus lies outside professional or technical education of any kind and maintains its autonomy by this distance.

However, industrialisation carried with it new demands on university education (Liedman, 1997: 222). The industrial state needed administrators, doctors and technicians and the university became the production site of such national resources. Economic and administrative utility started to compete with critique as a guiding principle of higher education. The twin demands for industrial competence and critical enquiry were not easy to reconcile. John Dewey, for instance, held that education primarily was about the 
individual's moral growth but should also prepare students for their roles as administrators or producers and as conscious citizens in a democratic community (Dewey, 2005). To Dewey, higher education was to serve both industry and democracy.

In many European universities, the tension between these aspects - critique versus entrepreneurialism -- of higher education (see Grey and French, 1996: 4) has, for a long time, been managed by means of organizational arrangements, where the twofold task has been divided between different faculties and departments. However, these organizational expedients no longer work so well. We contend that this two-legged function of universities has failed primarily because the philosophical/critical aspect is now, effectively, crippled. The professional/administrative training function, on the other hand, has been enormously strengthened. Thus, the latter has come to compensate for the fragility of the former. Miyoshi (2002), for instance, notes that writers on the institutional economy have very little to say about the humanities while humanities scholars appear oblivious to the tide of entrepreneurialism sweeping their departments "the two sides are oblivious to each other" (p. 69).

The picture is no less cheering in the case of technological and scientific disciplines. The funding crisis and the shortage of applicants in the technological sciences have, since it was first highlighted by Lord Robbins in the 1960s, continued their downward spiral. If one may speak from personal experience, one of the authors of this paper noted that not one of the two dozen or more science PhDs (chemistry, biology, mathematics, etc.) she met at Cambridge did not opt for careers in research after gaining their doctorates and chose instead to join 'industry'. Other examples point to the continuing decline in popularity of the sciences and the arts, with closures of chemistry and architecture 
departments in at least two well-known universities in the U.K. in recent years. Departments in the arts and humanities are seeing falling enrolments as students seek out subjects which will give them good career prospects, social prestige and higher pay.

In October 2010, the 'Independent Review of Higher Education Funding and Student Finance,' chaired by ex-BP boss, Lord Browne, dealt the arts and humanities a devastating blow: the current teaching grant distributed to English universities would be cut by $£ 3.2$ billion with a $100 \%$ reduction for the arts, humanities and social sciences. The cap of $£ 3290$ would be scrapped and universities would be allowed, technically, to charge unlimited fees for their products and services. The wholesale marketization and privatization of the arts and humanities in England did not pass without a national outcry led by students and academics but to no real avail. At the time of writing, the philosophy departments at Middlesex, Keele and Northampton Universities were all either battling closure or else were faced with the certainty of it (Morgan, 2011). It is clear that arts and humanities departments all over the country will now have to fight to survive the funding cuts. How the sector will fund future research remains very much an open question.

Sweden presents a similar picture. For the last ten years or so, humanities have struggled for their survival in an increasing utility-oriented academic culture (Schoug, 2008). The usefulness and relevancy of studies in humanities have been strongly questioned by economists and policy makers (Fölster, Kreicbergs and Sahlén, 2011) and for the last three years a debate referred to as "the crisis of humanities" has dominated the discourse on higher education in Sweden. In a report published by the Swedish Institute for Studies in Education and Research, it was shown that the humanities in Sweden suffers heavily 
from relatively very scarce resources $(6 \%$ of the total state investments in research and education) (Geschwind and Larsson, 2008).

The funding structure of U.K. universities further exacerbates threats to academic autonomy and freedom (Curie and Newson, 1998; Slaughter and Leslie, 1997). The inexorable rise in fees and the vast increase in student numbers have commodified the educational experience. In Sweden, higher education, although still funded entirely by the state (except for non-EU students), has, since 1993, in effect been based on market principles. State funding is tied to students' demand of the courses offered and the ratio of the number of admitted students and those who pass the courses (Swedish National Agency for Higher Education, report 2011). The funding of universities is hence contingent upon the ability to attract and produce (pass) students.

The funding structure of U.K. universities further exacerbates threats to academic autonomy and freedom (Curie and Newson, 1998; Slaughter and Leslie, 1997). The inexorable rise in fees and the vast increase in student numbers have commodified the educational experience. In Sweden, higher education, although still funded entirely by the state, has, since 1993, in effect been based on market principles. State funding is tied to students' demand of the courses offered and the ratio of the number of admitted students and those who pass the courses (Swedish National Agency for Higher Education, report 2006: 26). The funding of universities is hence contingent upon the ability to attract and produce (pass) students. 


\section{The market enters education: liberalism vs one-dimensionality}

As a consequence the university has to some extent become one-dimensional in the most Marcusean sense of the word, i.e. a place where thinking, writing and teaching conform to existing state of affairs rather than develop ideas that can transcend what is given and common sense (Marcuse, 1964). The universities thereby face the risk of losing its role as a progressive and reformist actor in society, and turn into little more than a factory of an efficient and smooth workforce of administrators, bureaucrats and technicians.

In the face of this development, academics who are still concerned with "truth" and "critique" are told not to despair because "universities are here to stay" (Tehranian, 1996, p. 446). Unless universities can maintain their critical edge, however, we do not think universities should simply stay around, even as the currently fashionable "virtual university" (Robins and Webster, 2002).

Two realities, therefore, have to be confronted in order for universities to be able to maintain its role as the critical gaze of society as well as to stay relevant to the market. Firstly, the survival of universities depends on the State, with all the limitations that go with that state of dependency. Secondly, and paradoxically, universities in the West are only fooling themselves if they think that all they need to do to survive is to follow the dictates of the State. They abandon their traditional function of critique at their peril because it is precisely this critical edge which grants universities their claim to autonomy. We wrote this paper because we believe that the university exists to "tell the truth, to judge, to criticize in the most rigorous sense of the term, namely to discern and decide between the true and the false" (Derrida, 2004: 97). We also believe that the university is 
a vital part of society and must find a way of reconciling the needs and demands of the market with this noble mission. The question, therefore, becomes, how can universities stay relevant to the market without suffering the erosion of its critical function?

\section{A New Role for Marketing Education?}

The clearest sign of an answer can be found in the surge in popularity of business schools and management education. In the last twenty years or so, the school of business or management stands out as the most successful and popular department in many universities around the world, both in terms of student enrolment and staff recruitment. Marketing education is of special interest in this respect.

It should be admitted, however, that marketing's status in academia as a critical and selfreflexive discipline, has been anything but self-evident. In the academic community, in universities and business schools, marketing has for quite sometime been involved in what Brown (cited in Alvesson and Willmott, 1996: 119) calls a 'perennial search for academic respectability'. Although things have changed since then, marketing education - with some excellent exceptions - is still running in the wake of, for instance, organization theory in terms of critical thinking.

That said, it is still - and perhaps consequently - our contention that the education of future marketers is a good site for nurturing and cultivating critical gazes. In fact, we wish to go further than that and suggest that marketing education is obliged to take on the responsibilities which come from being in a privileged position relative to the notion of critique. We suggest that critique needs not occur as some kind of privileged event from 
the "outside" of "the social world"; rather, we can think of critique as more effectively mobilized from an embedded position, from within sites of influence and power.

\section{Embedding Critics: The marketer as the "new intellectual"}

The concept of "embedding" critics in society is drawn from the strategy of embedding journalists in war zones. This practice was notably employed by the U.S. military during the invasion of Iraq in 2003, when journalists were planted in war zones, strongholds and military units normally completely inaccessible to civilians. After a crash course in military training, journalists were allowed to follow the everyday activities (battles) of a military unit (group or platoon) from within zones of conflict (for some discussion of embedded criticism, see the Fairness \& Accuracy in Reporting home page www.fair.org). Although initially criticized by observers as an instrument of betrayal and for putting journalists' lives at unnecessary and unacceptable risk, other commentators have pointed out the advantages of such a tactic for colluding with the enemy, whatever it or they are conceived of as being. The fact is that social theory often speaks of "embeddedness" in unproblematic terms, but the lines between the phenomenon and context are often blurred. Educators either choose to remain oblivious to this fact or else choose to ignore it. Yet, the concept of embeddedness can fruitfully be applied to higher education.

The notion of embedded critique, in fact, resonates with current debates not just in Europe, of course, but also (and perhaps even more intensely) in the context of the North American tradition of liberal education in colleges. Liberal education is based upon the idea of preparing the student for life and citizenship in democratic societies. 
Nussbaum (1998) relates the notion of liberal education to the training in ancient (classical) philosophy wherein the aim is to allow students to shine a light upon themselves as well as society, to reflect upon and transcend what is taken for granted and what is conceived of as 'natural' and 'traditional'. Higher education is thus conceived of as a means by which society "reveals itself as something unfinished, not as something inexorably given," (as a) "challenge rather than a hopeless limitation" (Freire, 2005: 15).

Just as journalists embedded in war zones expose critical failures and successes of national military operations and strategy, higher education works invisibly to expose, as well as illuminate, truths and falsehoods in society. In this sense, therefore, embeddedness can be conceived of as a vector of critical thinking in marketing education. Yet, the opportunities for exercising critical judgment and what Keats calls "negative capability" have hitherto escaped our students. Until now, that is. There is a window for this kind of embedded critique in the marketing curricula, for several reasons. As discussed earlier, the development of universities in both UK and Sweden reveals a trend of students opting for management education instead of more 'classical' humanities such as history and philosophy. The discipline of marketing (and management in general) seems to attract - or distract is perhaps a better term here - students from the traditional critical leg of university to the one engaged in production of useful administrators. While the academic tendency is to be suspicious of commercial success and popularity as measured by numbers alone, we argue that, along with Russell (1993: 75), "the reasons for the rise and fall in the popularity of subjects are not entirely whims of fashion, but may also represent how far those subjects are in a healthy intellectual state, and how far they are at the cutting edge of the movement of ideas." 
Added to this development is the fact that the marketing discipline, in particular, appears to be singularly popular with students - "our subject is blossoming" (Saunders and Lee, 2005) - and study after study shows that students want to get a degree in marketing for a range of reasons and are willing to pay for it ${ }^{1}$. One of the most commonly-cited reasons is the perceived ease of entry into interesting, well-paid jobs in marketing in virtually any industry. The position of marketing manager, marketing director, and Chief Marketing Officer appear to be both accessible as well as prestigious to the average student. More importantly, leadership positions in marketing appear to be more desirable than "making it to CEO," as students put it. In the wake of highly-publicised corporate scandals, none but the most careerist students in business schools regard the position of CEO or CFO as either professionally secure, morally praiseworthy or politically desirable.

As a result, class sizes in both mainstream courses and MBA programmes with a specialism in Marketing are swelling in greater and greater numbers and show no signs of slowing down. Moreover, marketing has grown steadily, theoretically and empirically; it is 100 years old and shows no signs of slowing down (see Jones and Monieson, 1990). The strength and dynamism of its self-awareness as a historically sound discipline is clear (Jones and Cunningham, 1997; Fisk, 1999; Hollander, 1998; Levy, 1999). It is also now well-established as a multidisciplinary field of study. In the last few years, it has attracted prominent academics with backgrounds in sociology, philosophy, literature, cultural

\footnotetext{
1 This observation holds true despite a recent paper by Saunders and Wong (2011) which argues (convincingly, in our view) that the quality of marketing research in the U.K. has been negatively affected by universities' focus on the RAE and its metrics. The decline in the quality of research outputs, however, is quite a separate matter from the continuing popularity of marketing courses among students who enroll on business and management programmes in the U.K.
} 
studies, information systems, and others, including business studies (accounting, finance, economics). While many problems remain within the marketing academy, there is undoubtedly a lively, engaged and dynamic research community focused on reflexively addressing issues of a critical nature.

The second reason why marketing is an apposite candidate for the embedded critic has to do with the role of market exchange in society and social life. The first observation, perhaps a trivial one, that can be made in this respect is that marketers play a significant role in the everyday maintenance of consumer society. Featherstone, for instance, draws the attention to a new group of what he, echoing Bourdieu, refers to as 'the new intellectuals'. This group has emerged from and within contemporary consumer society, and its members:

are engaged in providing symbolic goods and services -- the marketing, advertising, public relations, radio and television producers, presenters, magazine journalists, fashion writers. (Featherstone, 1991: 44)

The 'new intellectuals' are specialists in the production and distribution of symbols, taste and ideal lifestyles. Consequently, the marketer has been depicted as one of the main cultural architects of our time. It has been argued that marketing has come to play a significant role in the creation, maintenance and/or reproduction of taste, dreams and aspirations (Ewen, 1976; Lasch, 1979), needs (Packard, 1957), selves and identities (Willis, 1990; Kellner, 1992, Elliot, 1999), desiring consumers (Bauman, 2001), morality 
(Grafton-Small and Linstead, 1989), modernity and consumer culture (Arvidsson, 2003), materiality and hedonism (Pollay, 1986), and sign systems (Baudrillard, 1988, 1990).

Given the increased popularity of business courses it would seem logical to expect students who have taken 'marketing courses' to appear in more or more sectors of society. They may not have job titles that explicitly reflect their training or course of study, but it is already the case that marketing specialists hold positions of influence in a variety of professions (e.g. Mautner, 2010). Branding has for instance become a more common practice in the framing of cultural production. Thus, cultural institutions such as operas, theatres, art galleries, museums and music festivals, facing market competition and the need to be in demand, often draw on branding logic in the development of the enterprise (cf. Carah, 2011). Similarly, charity organizations have found it increasingly necessary to define themselves and to work within the discourse of marketing and branding as a way of increasing their impact (Bajde, 2009; Hankinson, 2001).

As we have said, universities, too, have been required to look upon themselves as competitors on the students' market. This development is symptomatic of broader changes in society: a trend for students to move from the traditional disciplines, from where critique has traditionally been advanced and taught, to newer disciplines that have historically been preoccupied with the production of useful and skilled administrators of the state and/or the market (the distinction between the two is nowadays not easily drawn). In addition to this, it is possible to argue that the 'marketer', in every conceivable disguises, assumes a highly central position in the everyday maintenance and reproduction of market(ized) society. 


\section{The Embedded Critic: Implications for Teaching Practice}

In our vision, marketing education needs to engage students in a critical debate the immediate 'practical' utility of which is not always clear to them initially. We now examine some practical implications of our thesis "embedding" critical marketing education.

As mentioned previously, critique involves the acknowledgement of practices of domination and mystification. Arguably, critical education should thus aim at facilitating the development of an awareness - a critical awareness. The awakening of critical awareness as discussed by Freire (1974:15) is of particular relevance for our theoretical framework. The development of critical awareness involves getting the students to perceive, experience - and indeed to fully embody - the political contradictions and tensions characterising practices of domination in contemporary society.

According to Freire (2005), there is no surer way to create distance between teacher and student than lecturing on critique. Freire, therefore, advocates the need for dialogue to provide opportunities for conscientization. We would add that this dialogue is not devoid of pain. To some extent, all learning involves pain in the sense that changing one's viewpoint and learning how to conceive of the world (or aspects thereof) differently is potentially uncomfortable for the learner. What, then, are the key aspects of this dialogue which marketing education can use and embed in the curriculum? 
First, the development of critical awareness orbits the relation between alienation and recognition of political and social tensions in the future world of the marketing students. Such political tensions include issues such as power relations between producers and consumers, the politics of consumer needs, social issues related to internalization and so forth. On the one hand, a certain distance to what is taken as given needs to be achieved. In dialogical moments in e.g. case discussions, seminars and debates, common sense must be translated into something strange in need of explanation. The ordinary needs to be rendered extra-ordinary. On the other hand, political tensions such as the above mentioned need to be recognised insofar as they do not appear as all too alien - and extraordinary - for the marketing student. Needless to say this is an act of balance that offers many challenges for the critical marketing teacher.

Secondly, the development of critical awareness involves being moved. Being moved should here be understood in two senses. To get involved in a process of conscientization the student has to be moved (metaphorically and metaphysically) from one standpoint from which the universe and 'discourse' of marketing, as it were, is understood, to another point of view from which the very same universe appears in an alternative (and perhaps less attractive) fashion. The student thus needs to be 'moved' from one horizon of insight into another. As aforementioned, this movement involves a certain extent of violence. It hurts to be pushed from the safe harbour of unquestioned truths to the wild sea of alternatives and problematizations. The second meaning of the student being moved connotes the emotional movement of not only seeing something from another point of view, but also realizing and embodying this viewpoint. Physical and emotional reactions, such as fear, anxiety, disgust and rage are invaluable for the conscientization of 
marketing students. Such emotional moments are arguably important bricks in the building of critical awareness. Being aware involves not only knowledge of state of affairs and critical theories and concepts, but also a more immediate emotional reactions such as fear, anxiety and rage.

\section{Conclusion and discussion}

To return to the question with which we began this paper: where should critique reside now, when the critical-philosophical aspect of higher education is seriously in decline? The answer offered in this paper is twofold, representing two separate moments of the embedding of critique and critics.

First, concerning the practice of university education, we have suggested that given the historical development of higher education - the decline of the humanities in addition to the reinforcement of management and marketing education - marketing education has become one of the most suitable candidates for the preparation of future professionals to engage in market critique from the very hub of market society. In other words, there are strong reasons for reviving critique from where the resources are, i.e. where the demand from students and state can be found. Hence, market critique is here, somewhat ironically, situated where resources have been allocated by market forces. This is the first moment, as it were, of embedding the critic and critique: within market-oriented educational practice. Secondly, with respect to the practice of marketing, marketing practitioners of the future will then be embedded at the very centre of market relations and exchanges from where a different sort of critique - in contrast to the one advanced from the periphery - can be performed. This is hence the second moment of the 
embedding enterprise by way of which the marketer is embedded in market society. From the core of the latter critique can be raised as well as incorporated in the work.

Embedding critique in this mode is not without risks. Critique as we often know it is commonly conceived of as advancing from the margins, from the periphery rather than the centre. Perhaps, some would argue, this centripetal direction is part of the very constitution of critique. Critique in the arts or politics which develops into an established practice, for instance, by becoming either a commodity in a market or state-financed (and thereby put under surveillance), very easily loses its critical edge. One thinks of graffiti, for example, as a form of critical comment and resistance which has in some urban areas of Sweden been given the State's blessing if performed in controlled areas - that is to say, on walls provided (and thus controlled) by the municipal administration. Embedded critique thus runs the risk of being subsumed under the very logic of the market.

Nevertheless, although we wholeheartedly acknowledge these risks, we still argue for a centrifugal critique of market society, one that emerges from within the market, among marketing practitioners. The main argument this is the distribution and impact of critique. We contend that embedding market critics in the marketing collective and within the market might be one mode of bridging the gap between critical thinking and critical performance, between the seminar room and business practice.

This is not to suggest that critique from the margins (centripetal critique) has lost its function. On the contrary, a potentially productive point of encounter is where critique from outside meets critique from within; here resides a possibility for a dialectical tension 
of market critique that, at its best, can provide a dynamic critical discourse, one that does not end up in the heap of stagnant dichotomies such as theory/practice, progressive/conservative or ideology/reality.

Marketing education can play a significant role in the constitution of such a critical discourse. In doing so, the training of marketing practitioners would in effect fulfil Kant's ideal of philosophy's role in universities, i.e. as being situated outside and above the society, at the same time as this is being done from within a market(ized) society. The embedded critic - in the garment of the marketer - would hence here operate as an outsider situated inside. To put the outsider inside and to turn the insider into an outsider - is this not the future of critical marketing education? 


\section{References}

Alvesson, M. and Deetz, S. (2000) Doing Critical Management Research. London, Sage.

Alvesson, M. and Willmott, H. (1992) Critical Management Studies, Sage, London.

Arvidsson, A. (2003) Marketing Modernity: Italian Advertising from Fascism to

Postmodernity, London and New York, Routledge.

Bajde, D. (2009) 'Rethinking the Social and Cultural Dimensions of Charitable Giving', Consumption Markets \& Culture, 12 (1): 65-84.

Baudrillard, J. (1988) Selected Writings, Stanford, Stanford University Press.

Baudrillard, J. (1990) Revenge of the Crystal, London, Pluto Press.

Bauman, Z. (2001) 'Consuming Life', Journal of Consumer Culture, 1 (1): 9-29.

Benson, L. and I. Harkavy (2002) 'The Role of Community-Higher Education-School Partnerships in Educational and Societal Development and Democratization." Universities and Community Schools, 7 (1/2): 5-28.

Böhm, S and S. Spoelstra (2004) 'No critique', ephemera, 4(2): 94-100.

Bridgman, T. and Stephens, M. (2008) 'Institutionalizing Critique: A Problem of Critical Management Studies', ephemera, 8(3): 258-270.

Carah, N. (2011) 'Breaking into The Bubble: Brand-building labour and 'getting in' to the Culture Industry', Continuum: Journal of Media \& Cultural Studies, 25 (3): 427438.

Catterall, M., MacClaran, P. and Stevens, L. (2002) 'Critical Reflection in the Marketing Curriculum', Journal of Marketing Education, 24: 184-192. 
Curie, J. and Newson, J. (Eds.) (1998) Universities and Globalization: Critical Perspectives, London, Sage.

Czarniawska, B. and Genell, K. (2002) 'Gone Shopping: Universities on their Way to the Market', Scandinavian Journal of Management, 18: 455-474.

Delanty, G. (2001) 'The University in the Knowledge Society', Organization, 8 (2): 149153.

Derrida, J. (2004) Eyes of the University: Right to Philosophy 2 (trans. Jan Plug and others), Stanford, Stanford University Press.

Dewey, J. (2005) Democracy and Education, New Delhi, Cosmo Publishers.

Ehrenberg, R G. (1997) 'The American University: Dilemmas and Directions', in R. G. Ehrenberg (Ed.), The American University: National Treasure or Endangered Species, Ithaca NY, Cornell University Press.

Elliot, R. (1999) 'Symbolic Meaning and Postmodern Consumer Culture', in D.

Brownlie, M. Saren, R. Wensley, and R. Whittington (Eds.), Rethinking Marketing: Towards Critical Marketing Accountings, London, Sage, 112-125.

Ellis, N., Fitchett, J., Higgins, M., Jack, G., Lim, M., Saren, M., and Tadajewski, M. (2010) Marketing: A Critical Textbook, London, Sage.

Ewen, S. (1976) Captains of Consciousness: Advertising and the Social Roots of Advertising, New York, McGraw-Hill.

Fairclough, N. (1995) Critical Discourse Analysis: The Critical Study of Language, London, Longman.

Featherstone, M. (1991) Consumer Culture and Postmodernism, London, Sage.

Fichte, J.G. (1807) 'Deduzierter Plan einer zu Berlin zu errichtenden höheren Lehranstalt' (Plan Designed for an Institution of Higher Education to be Established in 
Berlin), in E. Anrich (Ed.), Die Idee der deutschen Universität (The Idea of the German University), Hermann Gentner, Darmstadt.

Fisk, G. (1999) 'Reflection and Retrospection: Searching for Visions in Marketing', Journal of Marketing, 63 (1), January, pp. 115-26.

Ford, J., Harding, N. and Learmonth, M. (2010) 'Who is it that will make Critical Management more Critical? Critical Reflections on Critical Management Studies, British Journal of Management, 1 (21): 71-81.

Foskett, N.H. (2011) 'Markets, Government, Funding and the Marketisation of UK Higher Education", in M. Molesworth, R. Scullion, \& E. Nixon (Eds.), The Marketisation of Higher Education and the Student as Consumer, Abingdon: Routledge, 25-38.

Freire, P. (1974/2007) Education for Critical Consciousness. London: Continuum. Fullerton, R. A. (1987) 'Historicism: What It Is, and What It Means for Consumer Research', in M. Wallendorf and P. Anderson, (Eds.), Advances in Consumer Research, 14, Provo, UT, Association for Consumer Research, 431-434.

Fullerton, R. A. (1988) 'How Modern is Modern Marketing? Marketing's Evolution and the Myth of the 'Production Era', Journal of Marketing, January, 52: 108-25.

Fölster, S., Kreicbergs, J. and Sahlén, M. (2011) Konsten att strula till ett liv: Om ungdomars irrvägar mellan skola och arbete [The Art of messing up a life]. Stockholm: Svenskt näringsliv [Confederation of Swedish Enterprise].

Geschwind, L. and Larsson, K. (2008) Om humanistisk forskning: Nutida villkor och framtida förutsättningar. Report 2008: 81. Stockholm: Swedish Institute for Studies in Education and Research.

Gibbs, P. (2001) 'Higher education as a Market: A Problem or a Solution?', Studies in 
Higher Education, 26(1): 85-94.

Gornitzka, Å., Maassen, P., Olsen, J.P., and Stensaker, B. (2007) ‘Europe of Knowledge’: Search for a New Pact', in P. Maassen and J. P. Olsen (Eds.), University Dynamics and European Integration, Springer, Dordrecht, 239-286.

Grafton-Small, R., and Linstead, S. A. (1989) 'Advertisement and Artefacts: Everyday Understanding and the Creative Consumer', International Journal of Advertising, 8 (3): 205-218.

Grey, C. and French, R (1996) Rethinking Management Education, London, Sage. Griffin, G. (2006) ‘Balancing Agendas: Social Sciences and Humanities in Europe’, Arts and Humanities in Higher Education, 5 (3): 229-41.

Hankinson, P. (2001) 'Brand Orientation in the Charity sector: A Framework for Discussion and Research', International Journal of Nonprofit and Voluntary Sector Marketing, 6: 231-242.

Hedmo, T. and Wedlin, L. (2008) 'New Modes of Governance: the Re-regulation of European Higher Education and Research', in European Universities in Transition: Issues, Models and Cases, Mazza, C., Quattrone, P. and Riccaboni, A., (eds), Cheltenham: Edward Elgar, 113-132.

Hemsley-Brown, J. (2011) 'Market Heal Thyself: the Challenges of a Free Market in Higher Education', Journal of Marketing for Higher Education, 21 (2): 115-132.

Hill, Mark E. and McGinnis, John. (2007) 'The curiosity in Marketing Thinking', Journal of Marketing Education, April, 29 (1): 52-62.

Hollander, S.C. (1998) 'My Life on Mount Olympus', Journal of Macromarketing, 15 (1): 86-106. 
Högskoleverket (Swedish National Agency for Higher Education) (2011) Statistics. $\begin{array}{lllll}\text { Retrieved } & \text { January } & 3 & 2012, & \text { from }\end{array}$ http://www.hsv.se/download/18.27d86368130216405a680002479/1108R-universitethogskolor-arsrapport-2011.pdf

Jones, D.G.B. and Cunningham, P. (Eds.) (1997) Marketing History Knows no Boundaries, Proceedings of the $8^{\text {th }}$ Conference on Historical Research in Marketing and Marketing Thought. Kingston, Ontario: Queen's University of Business.

Jones, D. G. B. and Monieson, D. D. (1990) 'Early developments in the philosophy of marketing thought', Journal of Marketing, 54: 102-113.

Kant, I. (1979) The Conflict of the Faculties (trans. Mary J. Gregor), New York, Arabis Books.

Kellner, D. (1992) Popular Culture and the Construction of Postmodern Identities. In S. Lasch, C. (1979) The Culture of Narcissism, New York, Norton.

Kennedy, K. (1997) Citizenship education and the modern state, London: Falmer Press. Levy, S. J. (1999) Brands, Consumers, Symbols and Research, Thousand Oaks, CA: Sage.

Liedman, S-E (1997) I skuggan av framtiden: Modernitetens idéhistoria [In the shadow of the future: The idea history of modernity], Bonnier Alba.

Low, George S., Fullerton, Ronald A., J. (1994) 'Brands, brand management, and the brand manager system: A critical-historical evaluation', Journal of Marketing Research, 31 (2): 173-190.

Lowrie, A. and Willmott, H. (2006) 'Marketing Higher Education: The Promotion of Relevance and the Relevance of Promotion', Social Epistemology, 20 (3-4): 221-240. Marcuse, H. (1964) One-Dimensional Man, Boston, Beacon Press. 
Mautner, G. (2005) 'The Entrepreneurial University: A Discursive Profile of a Higher Education Buzzword', Critical Discourse Studies, 2 (2): 95-120.

Mautner, G. (2010) Language and the Market Society: Critical Reflections on Discourse and Dominance. New York: Routledge.

May, T. and Perry, B. (2006) 'Cities, Knowledge and Universities. Transformations in the Image of the Intangible', Social Epistemology, 20 (3-4): 259-282.

Miyoshi, M. (2002) 'The university in the "global" economy', in K. Robbins and F. Webster (Eds.), The Virtual University? Knowledge, Markets, Management, Oxford, Oxford University Press.

Molesworth, M., Scullion, R. and Nixon, E. (Eds.) (2011) The Marketisation of Higher Education and the Student as Consumer. New York: Routledge.

Morgan, J. (2011) 'Keele's Philosophers Stare into the Abyss', Times Higher Education, 18 March. Accessed at http://www.timeshighereducation.co.uk/story.asp?storycode=415539 on 21 Feb. 2012.

Nevett, T. (1991) 'Historical Investigation and the Practice of Marketing', Journal of Marketing, July, 55: 13-23.

Noll, E. (Ed.) (1998) Challenges to Research Universities, Washington, D.C.: Brookings Institution Press.

Nussbaum, M. C. (1998) Cultivating Humanity. A Classical Defense of Reform in Liberal Education, Cambridge, Mass. and London: Cambridge University Press.

Packard, V. (1957) The Hidden Persuaders: Influence as Interpersonal Accomplishment, New York: McKay. 
Perry, B. (2006) 'Science, Society and the University: A Paradox of Values', Social Epistemology, 20 (3-4): 201-219.

Petkus, E. (2007) 'Enhancing the Relevance and Value of Marketing Curriculum Outcomes to a Liberal Arts Education', Journal of Marketing Education, April, 29 (1): $39-51$.

Pollay, R. W. (1986) 'The Distorted Mirror: Reflections on the Unintended Consequences of Advertising', Journal of Marketing, 50 (2): 18-36.

Readings, B. (1996) The University in Ruins. Cambridge: Harvard University Press.

Robins, K. and Webster, F. (Eds.) (2002) The Virtual university? Knowledge, Markets and Management, Oxford, Oxford University Press.

Russell, C. (1993) Academic Freedom, London and New York, Routledge.

Saunders, J. and Wong, (2011) 'Manoeuvring towards Research Decline: The RAE and the Decline of Britain's International Research Standing', European Journal of Marketing, 45 (4): 484-512.

Saunders, J. and Lee, N. (2005) "Whither Research in Marketing?" European Journal of Marketing, 39 (3/4): 245-260.

The Economist (2003) Which MBA?, $15^{\text {th }}$ ed., Economist Intelligence Unit, London, 205218.

SCB (Statistics Sweden) (2011) Higher Education. Applicants and admitted to higher education at first and second cycle studies autumn term 2011. Accessed 2012-01-02, at

http://www.scb.se/Statistik/UF/UF0206/2011T02/UF0206_2011T02_SM_UF46SM1 1 01.pdf 
Schoug, F. (2008) Humaniora i yrkeslivet [Humanities in the work life]. Report 2008: 249. Lund: Lund University.

Slaughter, S. and Leslie, L. (1997) Academic Capitalism: Politics, Policy and the Entrepreneurial University, Baltimore, MD: Johns Hopkins University Press.

Tadajewski, M. (2010a) 'Moving beyond Paradigm and Contextual Parochialism in Marketing Theory', Marketing Theory, 10: 442-443.

Tadajewski, M. (2010b) 'Toward a History of Critical Marketing Studies', Journal of Marketing Management, 26: 773-824.

Tadajewski, M. and Brownlie, D. (2008) (Eds.) Critical Marketing: Issues in Contemporary Marketing, Chichester: Wiley and Sons.

Tadajewski, M. and Hewer, P. (2011) 'Editorial: Paradigmatic and Geographic Diversity in Marketing Theory and Practice', Journal of Marketing Management, 28 (1/2): 1-7.

Tehranian, M. (1996), ‘The End of University?' The Information Society, 12: 441-447.

Tierney, W. G. (Ed.) (1997) The Responsive University: Restructuring for High Performance, Baltimore, Johns Hopkins University Press.

Urry, J. (2002) Global Complexity, Cambridge, Polity.

Webster, G. (2003) 'Corporate Discourse and the Academy: A Polemic', Industry and Higher Education, April, 85-90.

Willis, P. (1990) Common Culture, Buckingham, Open University Press. 